AL IBTIDA: JURNAL PENDIDIKAN GURU MI (2019) Vol 6 (2): 159-176

DOI: http://dx.doi.org/ 10.24235/al.ibtida.snj.v6i2.4931

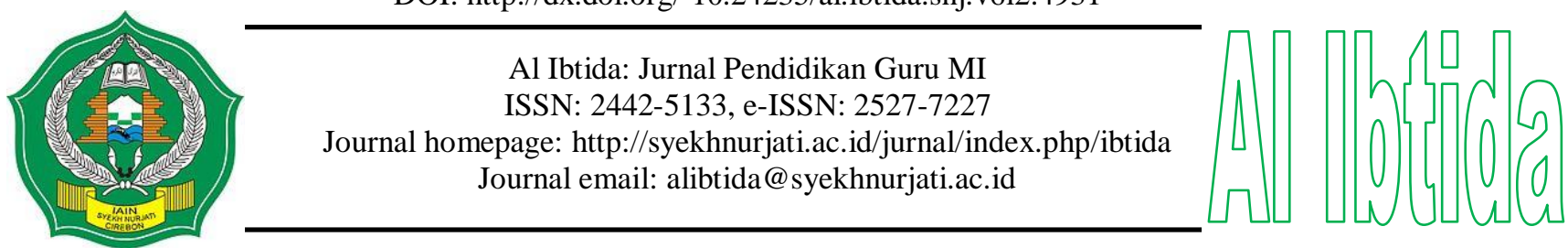

\title{
The Development of the 2013 Student Curriculum Book Based on Thinking Actively in Social Context for Elementary School Students
}

\author{
Hamimah* \\ *Study Program of Elementary Teacher Education, Faculty of Science Education, \\ Universitas Negei Padang \\ Email: hamimah@fip.unp.ac.id
}

Zuryanty**

**Study Program of Elementary Teacher Education, Faculty of Science Education, Universitas Negei Padang

Email: zuryantymeme@gmail.com

\author{
Ary Kiswanto Kenedi*** \\ ***Study Program of Elementary Teacher Education, Faculty of Science Education, \\ Universitas Samudra \\ Email: arykenedi@gmail.com
}

\begin{abstract}
Nelliarti*****
****Elementary School 26 Singkarak, Education Authorities, Solok Regency Government Email: nelliarti1967@gmail.com
\end{abstract}

Received: August $07^{\text {th }}, 2019$. Accepted: October 12 ${ }^{\text {th }}, 2019$. Published: October $2^{\text {th }}, 2019$.

\begin{abstract}
This research was motivated by the necessity of having student books that suit to the 2013 curriculum objectives, the characteristics of elementary school students and the characteristics of learning outcomes. The study aims to develop valid, practical, and effective elementary school student books based on thinking actively in social context. Employing a 4-D research model (define, design, development and disseminate), the data were garnered using tests, questionnaires, observations, interviews and documentation. The data from tests and questionnaires were analyzed using descriptive statistics whereas the triangulation was used to analyze the data collected through observations, interviews, and documentation. The results showed that the developed student books met the valid criteria with a final score of $85.25 \%$ (very valid). It was found that the student books are easy to use, time-saving, and useful to implement in the classroom practices. It could also enhance student learning outcomes in terms of spiritual attitudes, social, knowledge and skills with a percentage increase of $15.35 \%$. As those books are valid, practical, and effective; they can be used as a reference for the learning activities in elementary schools.
\end{abstract}

Keywords: student books, 2013 curriculum, TASC, elementary schools. 


\begin{abstract}
Abstrak
Penelitian ini dilatarbelakangi oleh perlunya buku siswa yang selaras dengan tujuan kurikulum 2013, karakteristik siswa sekolah dasar, dan karakteristik hasil belajar. Penelitian ini bertujuan untuk mengembangkan buku siswa kurikulum 2013 berbasis thinking actively in social context untuk sekolah dasar yang valid, praktis, dan efektif. Menggunakan model penelitian 4-D (define, design, development, disseminate), data dikumpulkan mealui tes, angket, observasi, wawancara dan dokumentasi. Data yang diperoleh dari tes dan angket dianalisis menggunakan statistik deskriptif sedangkan triangulasi digunakan untuk menganalisis data yang berasal dari observasi, wawancara, dan dokumentasi. Hasil penelitian menunjukkan bahwa buku siswa yang dikembangkan telah memenuhi kriteria valid dengan skor akhir $85,25 \%$ (sangat valid). Buku siswa mudah digunakan, menghemat waktu, dan bermanfaat dalam implementasinya pada pembelajaran di kelas. Buku siswa juga dapat meningkatkan hasil belajar siswa sekolah dasar pada aspek sikap spiritual, sosial, pengetahuan dan keterampilan dengan persentase kenaikan sebesar 15,35\%. Karena buku yang telah dikembangkan valid, praktis, dan efektif, buku siswa tersebut dapat dijadikan sebagai rujukan untuk kegiatan pembelajaran di sekolah dasar.
\end{abstract}

Kata kunci: buku siswa, kurikulum 2013, TASC, sekolah dasar.

\title{
INTRODUCTION
}

The curriculum system of primary schools has changed from the school-based curriculum to the 2013 curriculum as mandated in the Minister of Education and Culture Regulation number 67 of 2013 concerning the basic framework and structure of primary schools (Peraturan Menteri Pendidikan dan Kebuduayaan, 2013). This new curriculum aims at balancing the development of social attitudes, spiritual attitudes, cognitive abilities and psychomotor abilities (Maba \& Mantra, 2018; Subhan, Oktolita, \& Kn, 2018; Pamelasari, Nurkhalisa, \& Laksmana, 2018). The fundamental difference between the 2013 curriculum and the school-based curriculum is the integration of attitude values as a priority for developing primary knowledge without ignoring cognitive and psychomotor aspects.

The 2013 curriculum endeavors to equip graduates with valuable personalities. Personality is a creative, innovative, and productive attitude based on faith (Handayaningrum, 2016). The purpose of the 2013 curriculum is not only to develop knowledge and skills but also to strengthen student attitudes. Students put into practice their knowledge on the basis of faith and are responsible to bring about a mutual relationship between humans and its surroundings (Zulhernanda, 2018). In elementary school settings, students must be able to apply the value of attitudes in everyday life, either in interaction with fellow humans and natural surroundings or interaction with the almighty God. 
In the 2013 curriculum, the attitude domains comprise of two parts, namely a spiritual attitude and a social attitude (Ekawati, 2016). The spiritual attitude is the manifestation of interactions with the one and only God (Malaikosa, 2019; Widiyatmoko \& Shimizu, 2018). The development of spiritual attitudes in the 2013 curriculum is to strengthen the religious values in elementary schools. The realization of this practice is implemented in the learning process both inside and outside classrooms. The spiritual attitude is divided into several aspects such as observing worship, giving thanks, praying before and after carrying out an activity, and tolerance in worship (Rahmiwati, 2018; Martin, 2019). Meanwhile, the social attitude is the realization of human interaction and existence in social life (Widiyatmoko \& Shimizu, 2018). The social attitude in the 2013 curriculum aims to build students' noble character and enable students to be democratic, independent and responsible (Lili, 2016; Martin, 2019).

While attitudes focus on students' character, the domain of knowledge in the 2013 curriculum aims to enable elementary school students mastering science and technology (Martin, 2019). It must be able to allow them mastering all forms of science and technology including cultural arts and insights on world civilization (Widiyatmoko \& Shimizu, 2018). Thus, students can implement their knowledge to support the social aspects. Knowledge in the 2013 curriculum has a scientific dimension. This means that 2013 curriculum requires elementary school students to put their knowledge into practice.

The skills in the 2013 curriculum aim for primary school students to develop and create individuals who can think and act productively and innovatively (Martin, 2019). Skills contained in the 2013 curriculum must be able to make elementary school students think creatively, productively, and innovatively. Skills in the 2013 curriculum are proficient and creative. This means that students are required to be creative through the actions they take. Based on the elaboration on the 2013 curriculum, aspects of attitudes, knowledge, and skills in elementary schools must be able to create and shape students to behave based on the balanced knowledge and skills. Therefore teachers as subjects in the learning process in elementary schools must strive to achieve these goals.

Teachers have a big role in the learning process in the classroom (Nur \& Madkur, 2013). They must be able to create learning conditions to make it easier for students to achieve learning goals (Sieberer-nagler, 2016). Teachers can improve the quality of learning in various ways; one of which is through implementing innovative learning so that elementary school students can enjoy the learning process (Fiksl, Flogie, \& Aberšek, 2017). Elementary school students are in a concrete operational period (Kiswanto, 2017). Children in the concrete operational period learn from concrete things. Teachers must be able to present real learning so that elementary school students can easily build their knowledge. As elementary school students are in the active phase 
of moving (playing), teachers in primary schools must balance the process of delivering learning material by harmonizing the characteristics of elementary school students. Thus, in its implementation, learning must use a learning system while playing. It aims to maintain the mindset of students from abstract learning processes.

The 2013 curriculum seeks to harmonize learning to deal with the problems above. One effort to achieve this is the creation of teaching materials namely student books and teacher books. Teacher's books are made to make it easier for teachers to carry out the learning process while student books are created to make it easier for students to understand the materials.Student books are used as teaching materials in elementary schools. Student books in the 2013 curriculum are used as the main source of learning in elementary schools. This is because the student books present materials that suit tostudents' needs and are easy to carry.

Based on results of observation in the field, the teacher and student books used in the 2013 curriculum is now becoming a minimum standard of achievement and must be implemented by teachers and students. This is because the books were printed with national aims. However, some elementary schools must increase the content of the materials to meet the needs and characteristics of students in the regions.

Besides, the previous research stated that student books for elementary school students still have some weaknesses such as material discrepancies with themes, material discrepancies with students' cognitive development, and scientific approach discrepancies (Trianingsih, 2016). Also, there was a discrepancy between students' books and learning aspects in the 2013 curriculum, which comprises of spiritual, social, knowledge and skills. In some themes, it is rarely found a sentence that supports the aspect of spiritual attitudes. Besides, the aspect of social attitudes that emerges in the theme does not suit to the learning demands. While the aspect of skills needs to be developed further in accordance with the aspect of knowledge (Nova \& Habudin, 2017). This proves that the student books used today are still not perfect. This can be seen from the number of errors found in the contents.. This problem will affect the quality of learning and the students' achievement of the learning objectives. Then based on the analysis, the development of student books is needed to align the goals of 2013 curriculum, the characteristics of elementary school students and the suitability of the content materials in developing attitudes, knowledge, and skills.

The existing student books are scientific-based. The scientific approach was chosen because it can accommodate all aspects of the 2013 curriculum. This is the reason why this research is developed. Student books use a scientific approach combined with a learning approach that can align the 2013 curriculum goals, the characteristics of elementary school 
students and the suitability of content materials in developing attitudes, knowledge, and skills. This approach is called Thinking Actively in a Social Context and abbreviated as TASC.

TASC is a learning approach that consists of four elements derived from thinking and problem solving based development (Alkusaeri, 2013). TASC is a learning approach that enables thinking skills and problem-solving abilities to introduce different experiences. The results of thinking and problem-solving ability are explained into four elements. The four elements are (1) Thinking that aims to develop students' thinking abilities, especially the HOTS ability; (2) Actively that aims to allow students to understand, find out and express their opinions; (3) Social that aims to enable students to collaborate, interact, and share knowledge; (4) Context that aims to provide students with good basic concepts and learn from real experiences. This is the reason why researchers want to develop 2013 curriculum student books by considering the TASC elements. The purpose of the 2013 curriculum to align aspects of attitudes, knowledge, and skills has been summarized by the four elements of TASC.

Also, other studies reveal that TASC could improve students' attitudes and learning motivation, students' self-efficacy, problem-solving abilities, students' scholastic abilities in basic schools; it could also increase students' ability to make decisions and prepare students to be active in the social life (Wallace, Bernardelli \& Farrell, 2012; Septiyana \& Dasari, 2018; Wardhani, 2019; Samarapingavan, 1996). Based on these studies it can be concluded that TASC can improve the students' attitudes through the knowledge and skills owned by students. Based on the facts above, the purpose of this study is to develop valid, effective and practical 2013 curriculum student books for elementary school students. This research is a new study and has never been carried out by other researchers.

The state of the art in this study is based on the research conducted by Alhusaini (2018) who developed the TASC model for students with special needs to increase student creativity. The results of this study stated that the TASC model can increase the creativity of students with special needs. Also, a further research is conducted by Rosidi et al., (2013) whodeveloped biology learning tools using the TASC (Thinking Actively In Social Context) approach. The results stated that the development of this learning tool can improve the learning outcomes of high school students. From these two studies, we can conclude that the research objects of the previous research are students with special needs and high school students. Besides, the study investigated the development of learning models and tools. Therefore this is an innovation in this study. This research developed a TASC learning model with primary school student research as an object. Therefore the purpose of this study is to develop 2013 curriculum student books based on thinking actively in a social context for primary schools to be valid, practical and effective. 


\section{METHODS}

This is a development study using a 4-D model conducted at the 4th grade classof elementary schools. The 4-D development model consists of 4 stages, namely defining, design, development, and disseminate (Thiagarajan, 1974). First, the defining stage that aims to define and determine the needs in developing a prototype (Irawan, Padmadewi, \& Artini, 2018). At this stage, there are 5 activities carried out namely problem analysis, student analysis, task analysis, concept analysis, and learning objective analysis. At this stage, the data collection techniques are documentation and observation. Second, the design stage that aims to develop product designs based on the findings at the defining stage (Masrura, Indrawati, Arsyad, 2018). This stage consists of the preparation of instruments, sorting teaching materials, sorting formats and forming the initial design. At this stage, the data collection technique is documentation.

Third, the development stage that aims to develop a prototype plan created earlier. The final result of this stage is the production of elementary school student books. The activities at this stage are the expert validation and the limited development trials. Data collection techniques are interviews, observations, questionnaires, and tests. While interviews are used to see the results of expert validation, questionnaires try to see the results of practicality. Observations are conducted to see the students 'attitudes whereas tests aim to gather information regarding students' knowledge and skills (effectiveness). The qualitative data collected through interviews, observation, and documentation were analyzed using triangulation, while the quantitative data garnered through tests and questionnaires were analyzed using descriptive statistics with the scores obtained divided by maximum results then multiplied by 100 . Fourth, the disseminate stage aims to distribute products already made thus the benefits can be felt by other users. The disbursement is carried out in a limited way (Setiyadi, 2017).

\section{RESULTS AND DISCUSSION}

Based on the 4D stages namely define, design, development, and dissemination, the results and discussion are divided into four stages as follows:

Define stage. This stage consists of problem analysis, student analysis, task analysis, concept analysis, and learning goal analysis. First, from the problem analysis as explained in the background, there are many problems found in the student books for elementary school students. These problems include the number of inconsistencies in both social and spiritual attitude. Social and spiritual attitude are important in the 2013 curriculum because the objectives of the curriculum require students to have good personalities and good relationships between humans and the almighty God. In addition, there are mismatches of aspects of knowledge and skills in the 2013 curriculum. This will make it difficult for students to achieve learning goals. The 
student books are the main source in the learning process, therefore it must be able to help students in the learning. The student books in the 2013 curriculum have not been aligned with the objectives of the 2013 curriculum, the characteristics of elementary school students and the characteristics of learning outcomes.

Second, the student analysis. The student analysis in this study is viewed in terms of the cognitive development and student learning patterns. Based on the documentation, elementary school students are still in the age of 7-13 years. At this time, elementary school students are in a concrete operational period. This requires the teacher to conduct the learning process related to the student's real-life and it must be concrete. Also, based on observations, it appears that elementary school students like playing activities. This is in line with the psychomotor characteristics of students that elementary school-age children like motion activities. Playing is something loved by children at elementary school age. By playing, students can improve their experiences through movement activities. It will train students to think and practice, and also strengthen their social and emotional relationships.

Third, the task analysis. At this stage, the researcher analyzes the assignments in the student books. Based on observation and documentation, the tasks do not match with the materials. The tasks can be in the form of assignments for the three aspects; attitude, knowledge, and skills. Assignments for spiritual and social aspects are almost absent. This will make learning goals difficult to achieve. The tasks have an important role in achieving the learning objectives. Assignments can improve learning quality (Suryadi et al, 2017). Assignments given will enable students to understand the materials more easily.

Fourth, learning competency and material analysis. Competency and material analysis aim to determine the learning objectives of the materials that will be developed. This development starts with the understanding of the core and basic competencies in the 2013 curriculum. The 2013 curriculum consists of four core competencies namely CC 1 for spiritual aspect, C2 for social aspect, C3 for knowledge aspect, and CC 4 for skill aspect. The developed core competencies can be seen in the figure below.

Table 1. Core Competencies for Class IV

\begin{tabular}{|c|c|c|c|}
\hline $\begin{array}{l}\text { Core Competency I } \\
\text { (Spiritual attitude) }\end{array}$ & $\begin{array}{l}\text { Core Competency } 2 \\
\text { (Social attitude) }\end{array}$ & $\begin{array}{c}\text { Core Competency } 3 \\
\text { (Knowledge) }\end{array}$ & $\begin{array}{c}\text { Core Competency } 4 \\
\text { (Skill) }\end{array}$ \\
\hline $\begin{array}{l}\text { Accept and carry out } \\
\text { the religion they } \\
\text { profess. }\end{array}$ & $\begin{array}{l}\text { Show honest } \\
\text { behavior, discipline, } \\
\text { responsibility, polite, } \\
\text { caring, and confident } \\
\text { in interacting with } \\
\text { family, friends, } \\
\text { teachers, and }\end{array}$ & $\begin{array}{l}\text { Understand factual } \\
\text { knowledge by } \\
\text { observing (listening, } \\
\text { seeing, reading) and } \\
\text { asking questions } \\
\text { based on curiosity } \\
\text { about himself, God's }\end{array}$ & $\begin{array}{l}\text { Present factual } \\
\text { knowledge in clear, } \\
\text { systematic and } \\
\text { logical language in } \\
\text { aesthetic works, in } \\
\text { movements that } \\
\text { reflect healthy }\end{array}$ \\
\hline
\end{tabular}




\begin{tabular}{|c|c|c|}
\hline neighbor. & $\begin{array}{l}\text { creatures and their } \\
\text { activities, as well as } \\
\text { objects they } \\
\text { encounter at home } \\
\text { and school. }\end{array}$ & $\begin{array}{l}\text { children, and in } \\
\text { actions that reflect } \\
\text { the behavior of } \\
\text { children of faith and } \\
\text { noble character. }\end{array}$ \\
\hline
\end{tabular}

After finding the core competencies, the next step is analyzing the basic competencies to be developed. The Basic Competencies are developed as the following picture:

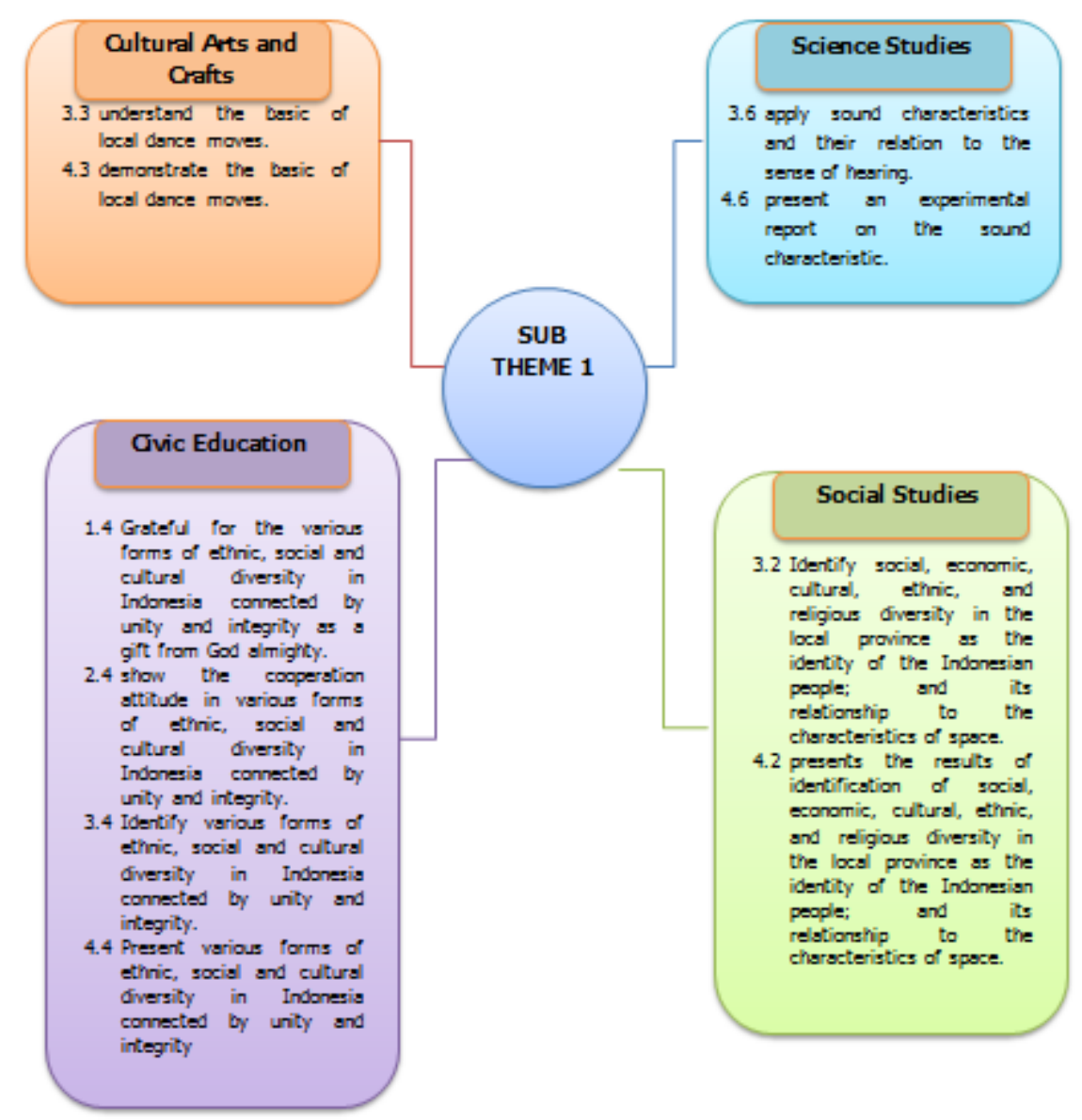

Figure 1. Basic Competence

After Basic Competence is developed, the next step is to analyze the learning activities and the potential developed. The results can be seen in the table 2 below.

Table 2. Learning Activities and Competencies Developed

\begin{tabular}{lll}
\hline Learning & \multicolumn{1}{c}{ Learning Activities } & \multicolumn{1}{c}{ Developed Competencies } \\
\hline 1 & 1. Find the main and supporting & Spiritual attitude: Gratitude and \\
ideas of the written text. & tolerance \\
& 2. Identify diversity. & Social attitude: Caring, polite. \\
3. Conduct experiments on how to & Knowledge: \\
& produce sound. & 1. The main and supporting ideas. \\
& & 2. Social and cultural diversity. \\
& 3. Sound characteristics. \\
& & Skills: \\
& & 1. Finding information, communicating \\
& results, analyzing, and concluding. \\
& 1. Find traits. & Spiritual Attitude: Gratitude and \\
\hline 2 & &
\end{tabular}


2. Dance regional dance (Bungong tolerance Jeumpa).

3. Identify diversity.

Social attitude: Caring, polite.

Skills:

1. Exercise the body, classify, communicate results.

Knowledge:

1. Basic dance moves.

2. Diversity.

\begin{tabular}{|c|c|c|}
\hline 3 & $\begin{array}{l}\text { 1. Find patterns from incoming and } \\
\text { outgoing data. } \\
\text { 2. Look for information on the } \\
\text { diversity of regional preferred } \\
\text { resources. } \\
\text { 3. Explain the effect of the time } \\
\text { difference. }\end{array}$ & $\begin{array}{l}\text { Spiritual attitude: Gratitude and } \\
\text { tolerance } \\
\text { Social attitude: Caring, polite. } \\
\text { Skills: } \\
\text { 1. Walk, run, jump, analyze and } \\
\text { conclude, look for information. } \\
\text { Knowledge: } \\
\text { 1. Locomotor and non-locomotor base } \\
\text { motion } \\
\text { 2. Characteristics of sound } \\
\text { disseminating. } \\
\text { 3. Main and supporting ideas. }\end{array}$ \\
\hline 4 & $\begin{array}{l}\text { 1. Find the main and supporting } \\
\text { ideas of the text. } \\
\text { 2. Demonstrate the importance of } \\
\text { unity. }\end{array}$ & $\begin{array}{l}\text { Spiritual attitude: Gratitude and } \\
\text { tolerance } \\
\text { Social attitude: Caring, polite } \\
\text { Skills: } \\
\text { 1. Classifying, seeking information, } \\
\text { communicating results. } \\
\text { Knowledge: } \\
\text { 1. The main and supporting ideas. } \\
\text { 2. Unity and integrity. }\end{array}$ \\
\hline 5 & $\begin{array}{l}\text { Dance regional dance (Bungong } \\
\text { Jeumpa). } \\
\text { Present the diversity. }\end{array}$ & $\begin{array}{l}\text { Spiritual attitude: Gratitude and } \\
\text { tolerance } \\
\text { Social attitude: Caring, polite } \\
\text { 1. Skills: } \\
\text { Classifying, seeking information, } \\
\text { communicating results. } \\
\text { Knowledge: } \\
\text { 1. Classifying, communicating results, } \\
\text { bodywork. }\end{array}$ \\
\hline 6 & $\begin{array}{l}\text { 1. Find the main and supporting } \\
\text { ideas of the text. } \\
\text { 2. Present diversity. Practice the } \\
\text { basic motion procedures of } \\
\text { walking, running, jumping in a } \\
\text { fortress game and the Sodor } \\
\text { Wagon. }\end{array}$ & $\begin{array}{l}\text { Spiritual attitude: Gratitude and } \\
\text { tolerance } \\
\text { Social attitude: Caring, polite } \\
\text { Skills: } \\
\text { 1. Looking for information, } \\
\text { communicating results, locomotor. } \\
\text { Knowledge: } \\
\text { 1. Main and supporting ideas. } \\
\text { 2. Unity. } \\
\text { 3. Locomotor base motion. }\end{array}$ \\
\hline
\end{tabular}


The table 2 shows what competencies are developed. Based on this matter, the materials will be developed in student books. The determination of competencies needs to be developed in the learning process so that the learning is clearer and directed (Ismail et al., 2018). Competence as a learning goal must be achieved by students thus the quality of learning becomes better. From the define stage, it can be concluded that the need for the development of student books can align the 2013 curriculum objectives, student characteristics and learning outcomes components consisting of aspects of spiritual attitude, social, knowledge, and skills.

The next stage is the design. This aims to plan the prototype format to be developed. This stage consists of designing the prototype validation and the initial design. The design of prototype validation consists of the eligibility aspect, the presentation eligibility aspect, the language eligibility aspect, the TASC assessment aspect. Whereas the initial design consists of a format like a table below.

Table 3. Prototype Design

\begin{tabular}{ll}
\hline \multicolumn{1}{c}{ Design } & \multicolumn{1}{c}{ Explanation } \\
\hline Cover and Title & $\begin{array}{l}\text { The cover is made as attractive as possible by including the title of the } \\
\text { theme, the identity of the book (Thematic Actively in Social Context } \\
\text { Curriculum Students' Integrated Thematic Students Book). The cover } \\
\text { uses a cartoon background of elementary school students are studying. } \\
\text { Student books have learning instructions that make it easier for } \\
\text { students to use this book. Study instructions will be made to guide } \\
\text { students through TASC by referring to aspects of spiritual attitude, } \\
\text { social, knowledge, and skills. } \\
\text { This book will display core and basic competencies thus students } \\
\text { understand the learning objectives to be achieved } \\
\text { Competency }\end{array}$ \\
Theme network & $\begin{array}{l}\text { This theme network will make it easier for students to see the } \\
\text { interrelationships between lessons. } \\
\text { In the student book learning activities will be made. This learning } \\
\text { activity uses the TASC approach } \\
\text { This student book will be equipped with pictures that make it easier } \\
\text { for students to understand the material visually. }\end{array}$ \\
\hline
\end{tabular}

From table 3 , this design aims to simplify the development process. The prototype designed must be following the results of defining the problem thus the purpose of development can be following the target.

Development stage. The development phase is the implementation of the plan made before. Developed student books are then subjected to expert validation. Validation was carried out three times. When the validator gives the information, the next step is revising until the data provided is valid. The conclusions of the validation results are as follows: 
Table 4. Conclusion of Content Feasibility Aspect Validation

\begin{tabular}{|c|c|c|c|}
\hline \multicolumn{4}{|c|}{ Content Feasibility Aspect } \\
\hline $\begin{array}{c}\text { Assessment } \\
\text { Indicator }\end{array}$ & $\begin{array}{c}\text { Expert statement } \\
\text { (Revision 1) }\end{array}$ & $\begin{array}{c}\text { Expert statement } \\
\text { (Revision 2) }\end{array}$ & $\begin{array}{c}\text { Expert statement } \\
\text { (Revision 3) }\end{array}$ \\
\hline $\begin{array}{l}\text { Material } \\
\text { suitability } \\
\text { with basic } \\
\text { competencies }\end{array}$ & $\begin{array}{l}\text { The need to add } \\
\text { completeness, breadth, and } \\
\text { depth to the material }\end{array}$ & $\begin{array}{l}\text { The material } \\
\text { presented needs to be } \\
\text { explored }\end{array}$ & $\begin{array}{l}\text { The material is } \\
\text { following Basic } \\
\text { Competency }\end{array}$ \\
\hline $\begin{array}{l}\text { Material } \\
\text { accuracy }\end{array}$ & $\begin{array}{l}\text { Concepts and definitions are } \\
\text { not very accurate, data and } \\
\text { facts need to be adjusted, } \\
\text { examples and cases in } \\
\text { books are following student } \\
\text { characteristics }\end{array}$ & $\begin{array}{l}\text { Develop further } \\
\text { example and case } \\
\text { accuracy }\end{array}$ & $\begin{array}{l}\text { The material as a } \\
\text { whole is accurate. }\end{array}$ \\
\hline $\begin{array}{l}\text { Material } \\
\text { updates }\end{array}$ & $\begin{array}{l}\text { Connect images with } \\
\text { everyday life }\end{array}$ & $\begin{array}{l}\text { Adapt the example to } \\
\text { events close to } \\
\text { students }\end{array}$ & $\begin{array}{l}\text { The material } \\
\text { developed is the } \\
\text { latest material }\end{array}$ \\
\hline $\begin{array}{l}\text { Encourage } \\
\text { curiosity }\end{array}$ & $\begin{array}{l}\text { The material does not } \\
\text { arouse student curiosity }\end{array}$ & $\begin{array}{l}\text { Some materials tend } \\
\text { to be a statement }\end{array}$ & $\begin{array}{l}\text { Student books can } \\
\text { encourage student } \\
\text { knowledge }\end{array}$ \\
\hline
\end{tabular}

Table 5. Conclusion of Presentation Eligibility Aspect Validation

\begin{tabular}{llll}
\hline \multicolumn{1}{c}{$\begin{array}{c}\text { Assessment } \\
\text { Indicator }\end{array}$} & $\begin{array}{c}\text { Expert statement } \\
\text { (Revision 1) }\end{array}$ & $\begin{array}{c}\text { Expert statement } \\
\text { (Revision 2) }\end{array}$ & $\begin{array}{c}\text { Expert statement } \\
\text { (Revision 3) }\end{array}$ \\
\hline $\begin{array}{l}\text { Presentation } \\
\text { Technique }\end{array}$ & $\begin{array}{l}\text { Presentation is still } \\
\text { not coherent }\end{array}$ & $\begin{array}{l}\text { Presentation is } \\
\text { coherent }\end{array}$ & \\
$\begin{array}{l}\text { Supporting the } \\
\text { presentation }\end{array}$ & $\begin{array}{l}\text { Need to add } \\
\text { questions, } \\
\text { contextual exercise, } \\
\text { provide answer } \\
\text { keys, add a glossary }\end{array}$ & $\begin{array}{l} \\
\text { and bibliography } \\
\text { the question is still }\end{array}$ & \\
& $\begin{array}{l}\text { Raise TSC } \\
\text { characteristics }\end{array}$ & & \\
Learning & & - & - \\
Presentation & &
\end{tabular}

Table 6. Conclusion of Language Feasibility Aspect Validation

\begin{tabular}{lllc}
\hline \multicolumn{1}{c}{$\begin{array}{c}\text { Assessment } \\
\text { Indicator }\end{array}$} & \multicolumn{1}{c}{$\begin{array}{c}\text { Expert statement } \\
\text { (Revision 1) }\end{array}$} & $\begin{array}{c}\text { Expert statement } \\
\text { (Revision 2) }\end{array}$ & $\begin{array}{c}\text { Expert statement } \\
\text { (Revision 3) }\end{array}$ \\
\hline Straightforward & $\begin{array}{l}\text { Some sentences are still } \\
\text { chaotic, there are some } \\
\text { nonstandard sentences }\end{array}$ & $\begin{array}{l}\text { There are some } \\
\text { ineffective sentences }\end{array}$ & Valid \\
\hline $\begin{array}{l}\text { Communicative } \\
\text { is still abstract }\end{array}$ & $\begin{array}{l}\text { Already good } \\
\text { The text is still a }\end{array}$ & Already good & Valid \\
monologue & $\begin{array}{l}\text { Some sentences need to } \\
\text { be simplified }\end{array}$ & $\begin{array}{l}\text { There are still } \\
\text { abstract sentences }\end{array}$ & Valid \\
\hline $\begin{array}{l}\text { Conformitive } \\
\text { students }\end{array}$ & & & \\
\hline
\end{tabular}




\begin{tabular}{llll}
\hline $\begin{array}{l}\text { Conformity with } \\
\text { rules }\end{array}$ & $\begin{array}{l}\text { The grammar is still } \\
\text { wrong }\end{array}$ & Incorrect spelling & Valid \\
\hline
\end{tabular}

Table 7. Conclusion of TASC Aspect Validation

\begin{tabular}{|c|c|c|c|}
\hline \multicolumn{4}{|c|}{ TASC Aspects } \\
\hline $\begin{array}{l}\text { Assessment } \\
\text { Indicator }\end{array}$ & $\begin{array}{l}\text { Expert statement } \\
\quad(\text { Revision 1) }\end{array}$ & $\begin{array}{c}\text { Expert statement } \\
\text { (Revision 2) }\end{array}$ & $\begin{array}{l}\text { Expert statement } \\
\text { (Revision 3) }\end{array}$ \\
\hline Identify & $\begin{array}{l}\text { Problems in the text are still } \\
\text { not contextual }\end{array}$ & $\begin{array}{l}\text { Sentences in the text } \\
\text { must be simpler }\end{array}$ & Valid \\
\hline Generate & $\begin{array}{l}\text { This stage is still not visible in } \\
\text { student books }\end{array}$ & $\begin{array}{l}\text { This stage still seems } \\
\text { forced }\end{array}$ & Valid \\
\hline Decide & $\begin{array}{l}\text { Decide is too small so it will be } \\
\text { difficult for students to } \\
\text { determine ideas }\end{array}$ & Already good & Valid \\
\hline Implement & $\begin{array}{l}\text { Implement instructions are } \\
\text { more clarified }\end{array}$ & Already good & Valid \\
\hline Evaluate & $\begin{array}{l}\text { Some evaluate clues are still } \\
\text { ambiguous }\end{array}$ & $\begin{array}{l}\text { There are still } \\
\text { ambiguous evaluate } \\
\text { clues }\end{array}$ & Valid \\
\hline Communicate & Already good & Already good & Valid \\
\hline $\begin{array}{l}\text { Learn From } \\
\text { Experience }\end{array}$ & $\begin{array}{l}\text { At this stage students are asked } \\
\text { to write before submitting }\end{array}$ & Already good & Valid \\
\hline
\end{tabular}

Table 8. Conclusion of Content Feasibility Aspect Validation

\begin{tabular}{llc}
\hline No & \multicolumn{1}{c}{ Validator } & Final score \\
\hline 1 & Content Feasibility Aspect & 83 \\
2 & Presentation Aspect & 87 \\
3 & Language Feasibility & 86 \\
4 & TASC Aspect & 85 \\
\hline & Average & 85,25 \\
\hline
\end{tabular}

After the product is validated, a revision is made to improve the prototype. Based on the assesment of experts from table 4 , table 5 , table 6 , table 7 , and table 8 ; it can be concluded that the prototype was valid in terms of the feasibility aspect, the presentation eligibility aspect, the language eligibility aspect, and TASC aspect. The prototype was suitable for use. A product will be validated by experts in their field (Hendryadi, 2017). Validity has a reference regarding the accuracy of measurements. Validity aims to help researchers to examine product service in terms of concepts and operations (Growth, 2010). Therefore every aspect that cannot be measured quantitatively can be measured qualitatively by involving experts.

The next step is a limited trial of student books for elementary school students. The assessment is carried out in the form of evaluating spiritual attitude, social attitude, knowledge, and skills. This limited test is carried out for a week by conducting an assessment every day. Spiritual attitude assessment focuses on gratitude and tolerance. Based on the observation on the first day, there were no events that showed gratitude and tolerance of students. On the second 
day, a student named A said "Thank God" when he got a high grade. On the third day, there was an incident when the group formed by the teacher was randomized again, the group was divided both in terms of religion, gender and social. Students did not not show a reaction of rejection. On the fourth day when the teacher stated that all students received good grades, Muslim students said the sentence Alhamdulillah. On the fifth day, Friday, all students exchanged greetings. It was a charity day, all students including non-Muslim students joined the charity. On the sixth day, students help each other in discussions without differentiating anything. The results prove that the attitude of gratitude and tolerance of students increases every day.

Based on the assessment of social attitudes such as polite and caring, it was found that students always kissed the teacher's hand every day. They never fought with each other. Students also show concerns on their surrounding environments such as putting trash into the dustbin and doing a class sanitation. This proves that students have practiced good manners and care in the learning process.

Knowledge aspects. Knowledge aspects can be seen from the results of student evaluations every day. The results of the evaluation can be seen in the graph 1 below:

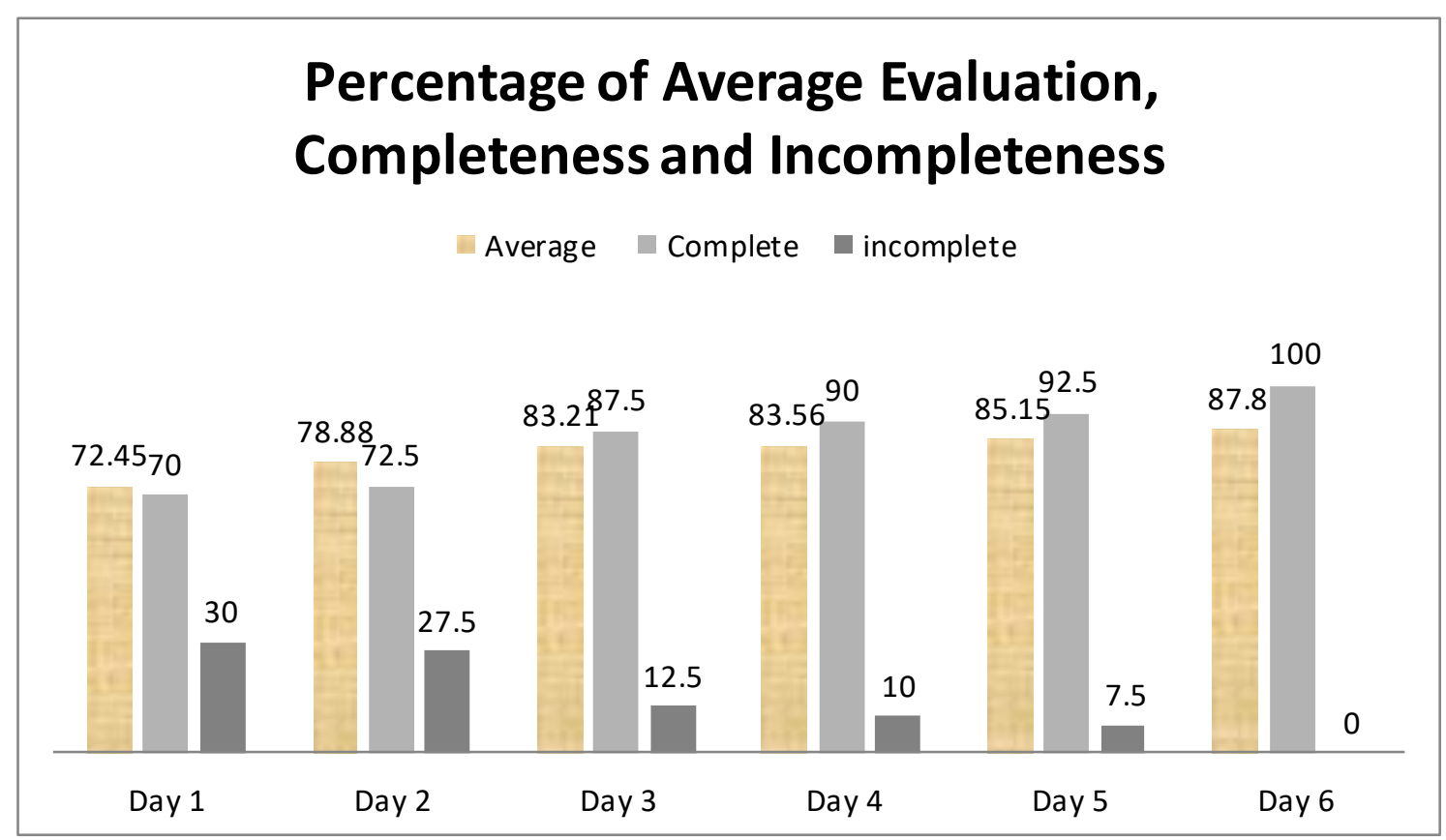

Graph 1. Average percentage of evaluation results, completeness and incompleteness

Based on graph 1 above, we can see that there is a periodic increase in the percentage of the average grade and alsoand the percentage of the number of students with the complete category. There is a decrease in the number of students with the incomplete category.

Based on the assessment of spiritual attitude, social, knowledge, and skills, we can conclude that the TASC-based student book is effective. Effectiveness is important in the learning process. Learning is effective when achieving learning objectives. The effectiveness of 
a learning device can be seen and measured from the achievement of students in the assessment of attitudes, knowledge, and skills (Santi \& Santosa, 2016). Consequently, based on the results and theories of the experts, we can conclude that the TASC-based student book is effective in improving the learning outcomes of elementary school students.

After it is implemented, the teacher and student practicality test is carried out. The student practicality test is seen from the ease of using the student books, time efficiency, and perceived benefits. Student practicality test can be seen in the graph 2 below:

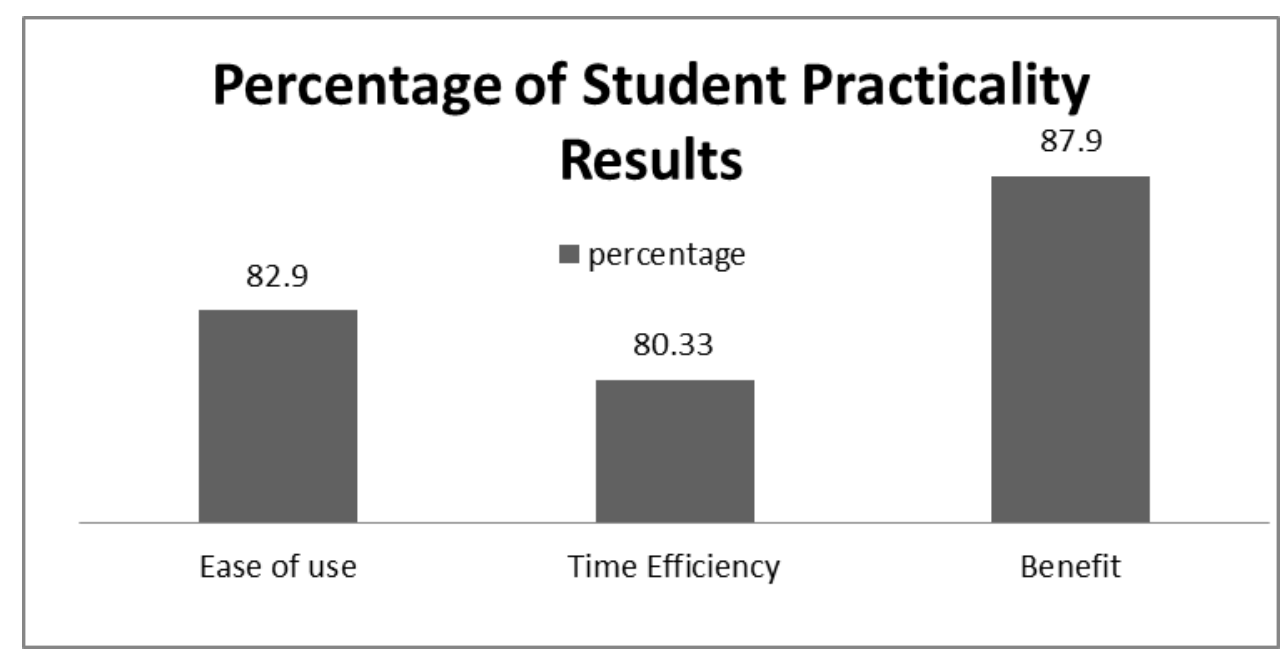

Graph 2. Student Practicality Test

Based on the range of practicality, ease of use and time efficiency are categorized as good and the benefits are very good.

Meanwhile, practicality is limited to teachers by conducting structured interviews with the following results:

T1 "Developed teaching materials are very easy to understand by students. Besides,

this student books allocate learning time clearer and can improve learning outcomes"

From the quote of the teacher's conversation, we can conclude that the TASC-based student book is practical. The practicality of teaching materials can be done with assessments conducted by teachers and students (Kharisma \& Asman, 2018). A teaching material is practical if it is in the good category (Hastutiningsih et al, 2016). Based on this, it can be concluded that the student book is practical.

Overall TASC-based elementary school student books are categorized as valid, practical and effective. It also proves that the TASC can align the 2013 curriculum goals, the characteristics of elementary school students and the characteristics of learning outcomes. TASC is a universal learning (Williams, 2011). TASC learning can be implemented in every learning to develop thinking skills and solve problems. TASC can stimulate the nerves in the mind to achieve success. This is what causes primary school student learning outcomes to improve 
because TASC will affect the mindset of students in finding solutions to any existing problems (Wallace, 2000). TASC with its four elements will influence the learning process (Alkusaeri, 2013). Thinking Element requires students to think statically thus it will affect the ability to think at a higher level in the aspects of attitude, knowledge, and skills (Mas \& Ntt, 2012). Actively Element will guide students to be involved in finding information (learning) so that students will be trained to behave, think and move (Tunnur, 2017). Social Element will require students to copy their interactions which will lead to good attitudes, sharing to increase knowledge and cooperation to improve skills. Last, Context Element requires students to connect the knowledge gained with everyday life. It also trains students' basic eco attitude, knowledge, and skills. Therefore, TASC learning is very suitable to be applied to students' books in achieving learning objectives.

\section{CONCLUSION}

Based on the description of the results of the research and discussion, it can be concluded that TASC-based elementary school student books are categorized as valid, practical, and effective. It also proves that the TASC can align the 2013 curriculum goals, the characteristics of elementary school students and the characteristics of learning outcomes. So, TASC-based elementary school student books can be a new source of learning for elementary school students.

\section{REFERENCES}

Alhusaini, A. (2018). Using the TASC Model to Develop Gifted Students' Creativity: Analytical Review. Journal for the Education of Gifted Young Scientists, 6(3), 11-29.

Alkusaeri, A. (2013). Pembelajaran Matematika dengan Model TASC (Thinking Actively in a Social Context). Beta: Jurnal Tadris Matematika, 6(1), 1-26.

Ekawati, Y. N. (2016). The Implementation of Curriculum 2013: A Case Study of English Teachers' Experience at SMA Lab School in Indonesia. English Language Learning Development (ELLD) Journal, 7(1), 84-90.

Fiksl, M., Flogie, A., \& Aberšek, B. (2017). Innovative Teaching/Learning Methods To Improve Science, Technology And Engineering Classroom Climate And Interest. Journal of Baltic Science Education, 16(6), 1009-1019.

Growth, G. (2010). Handbook of Psychological Assessment. Terj. Soetjipto, H.P \& Soetjipto, S.M. Yogyakarta: Pustaka Pelajar

Handayaningrum, W. (2016). Science-Based Thematic Cultural Art Learning in Primary School (2013 Curriculum). Harmonia: Journal Of Arts Research And Education, 16(1), 14-23.

Hastutiningsih, T., Prasetyo, A. P. B., \& Widiyaningrum, P. (2016). Pengembangan Panduan Pembelajaran Outdoor Bermuatan Karakter Peduli Lingkungan Pada Materi Ekologi. Journal of Innovative Science Education, 5(1), 28-35. 
Hendryadi, H. (2017). Validitas isi: tahap awal pengembangan kuesioner. Jurnal Riset Manajemen dan Bisnis (JRMB) Fakultas Ekonomi UNIAT, 2(2), 169-178.

Irawan, A. G., Padmadewi, N., \& Artini, L. P. (2018). Instructional materials development through 4D model. In SHS Web of Conferences, 42, 00086. EDP Sciences.

Ismail, I., Hasan, H., \& Musdalifah, M. (2018). Pengembangan Kompetensi Mahasiswa Melalui Efektivitas Program Magang Kependidikan. Edumaspul-Jurnal Pendidikan, 2(1), 124132.

Kharisma, J. Y., \& Asman, A. (2018). Pengembangan Bahan Ajar Matematika Berbasis Masalah Berorientasi pada Kemampuan Pemecahan Masalah Matematis dan Prestasi Belajar Matematika. Indonesian Journal of Mathematics Education, 1(1), 34-46.

Kiswanto, A. (2017). The Effect Of Learning Methods And The Ability Of Students Think Logically To The Learning Outcomes On Natural Sciences Of Grade IvS Student. In 9th International Conference for Science Educators and Teachers (ICSET 2017). Atlantis Press.

Lili, S, N. (2016). Learning Methods of Remote Sensing In the 2013 Curriculum of Secondary School. IOP Conference Series: Earth and Environmental Science, 47(1), 012045.

Maba, W., \& Mantra, I. B. N. (2018). The primary school teachers' competence in implementing the 2013 curriculum. SHS Web of Conferences, 42, 00035.

Malaikosa, C., \& Sahayu, W. (2019). Teachers' Challenges on Implementing EFL Curriculum in Indonesian Rural Area. Journal of Foreign Language Education and Technology, 4(1), 41-48.

Martin, S. N. (2019). Science education in Indonesia: past, present, and future. Asia-Pacific Science Education, 5(1), 1-29.

Mas, S., TK, P., \& NTT, S. K. M. B. (2012). Peningkatan Kemampuan Berpikir Kritis Siswa Kelas V SDI Daleng Manggarai Barat NTT pada Pokok Bahasan Globalisasi dengan Model TASL. Journal of Teacher Quality Improvement Programs, 3(1), 47-53.

Masrura, S. I., Indrawati, N., \& Arsyad, N. (2018). The Development of Learning Package Based on Metacognitive Strategies to Build the Students Character. Journal of Physics: Conference Series, 1028(1), 012127.

Nova, N., \& Habudin, H. (2017). Analisis Kesesuaian Isi Buku Teks Siswa Kelas IV SD/MI Tema Cita-Citaku Dengan Kurikulum 2013. Primary: Jurnal Keilmuan dan Kependidikan Dasar, 9(01), 111-130.

Nur, M. R., \& Madkur, A. (2014). Teachers'voices On The 2013 Curriculum For English Instructional Activities. IJEE (Indonesian Journal of English Education), 1(2), 119-134.

Pamelasari, S. D., Nurkhalisa, S., \& Laksmana, S. I. (2018). A comparison study of instruction between international school and state school of middle school level in Indonesia. Journal of Physics: Conference Series, 983(1), 012204.

Peraturan Menteri Pendidikan dan Kebuduayaan. (2013). Kerangka Dasar dan Struktur Sekolah Dasar/ Madrasah Ibtidayah. Lembaran Negara RI Tahun 2013, Nomor 67. Jakarta: Kemendikbud. 
Rahmiwati, S. (2018). The Implementation of Integrated Natural Science Textbook of Junior High School be Charged on Character-based Shared Models to Improve the Competence of Learners' Knowledge. IOP Conference Series: Materials Science and Engineering, $335(1), 012076$.

Rosidi, I., Ibrahim, M., \& Tjandrakirana, T. (2013). Peningkatan Kemampuan Berpikir Kreatif Siswa Menggunakan Perangkat Pembelajaran Biologi Dengan Pendekatan TASC (Thinking Actively In Social Context). JPPS (Jurnal Penelitian Pendidikan Sains), 2(2), 250-257.

Samarapingavan, S. (1996). TASC: Thinking Actively in a Social Context. Gifted and Talented International, 11(2), 91-92.

Santi, I. K. L., \& Santosa, R. H. (2016). Pengembangan Perangkat Pembelajaran menggunakan Pendekatan Saintifik pada materi pokok geometri ruang SMP. Pythagoras: Jurnal Pendidikan Matematika, 11(1), 35-44.

Septiyana, W., Asih, E. C. M., \& Dasari, D. (2019). The implementation of thinking actively in a social context learning model to improve the ability of mathematical literacy and selfefficacy of junior high school students. Journal of Physics: Conference Series, 1157(3), 032117.

Setiyadi, M. W. (2017). Pengembangan modul pembelajaran biologi berbasis pendekatan saintifik untuk meningkatkan hasil belajar siswa. Journal of Educational Science and Technology (EST), 3(2), 102-112.

Sieberer-Nagler, K. (2016). Effective Classroom-Management \& Positive Teaching. English Language Teaching, 9(1), 163-172.

Subhan, M., Oktolita, N., \& Kn, M. (2018, April). Developing Worksheet (LKS) Base on Process Skills in Curriculum 2013 at Elementary School Grade IV, V, VI. IOP Conference Series: Materials Science and Engineering, 335(1), 012108.

Suryadi, S., Erlamsyah, E., \& Yusri, Y. (2017). Hubungan Kemampuan Menyelesaikan TugasTugas Pelajaran Dengan Hasil Belajar Siswa. Jurnal EDUCATIO: Jurnal Pendidikan Indonesia, 2(2), 14-18.

Thiagarajan, S. (1974). Instructional development for training teachers of exceptional children: A sourcebook. Washinton Dc: National Center for Improvement of Educational Systems (DHEW/OE)

Trianingsih, R. (2016). Analisis Buku Kelas V Sd/Mi Kurikulum 2013 Pada Tema Kerukunan Dalam Bermasyarakat. Ar-Risalah, 17(1), 25-39.

Tunnur, R. (2017). Pengembangan Model IDACR untuk Meningkatkan Kemampuan Mengevaluasi Peserta Didik SMA pada Mata Pelajaran Fisika. In Prosiding Seminar Nasional Pascasarjana Unsyiah.

Wallace, B. (2000, Autumn). Teaching thinking and problem-solving skills. Educating Able Children, 20-23.

Wallace, B., Bernardelli, A., Molyneux, C., \& Farrell, C. (2012). TASC: Thinking actively in a social context. A universal problem-solving process: A powerful tool to promote 
differentiated learning experiences. Gifted Education International, 28(1), 58-83.

Wardhani, I. Y. (2018). Pembelajaran Thinking Actively In Social Context Untuk Meningkatkan Kemampuan Higher Order Thinking Siswa SMA. Journal Of Biology Education, 1(1), 116.

Widiyatmoko, A., \& Shimizu, K. (2018). An overview of conceptual understanding in science education curriculum in Indonesia. Journal of Physics: Conference Series, 983(1), 012044.

Williams, J. D. (2011). How science works, teaching and learning in the science classroom. Chennai: Continuum.

Zulhernanda, W. (2018). Teachers' perceptions on application of 2013 curriculum for elementary school in Medan. Advances in Language and Literary Studies, 9(1), 62-66. 